\title{
Thermomorphogenic Responses in Stem and Leaf Development
}

\author{
John E. Erwin \\ Department of Horticultural Science, University of Minnesota, St. Paul, MN 55108 \\ Royal D. Heins \\ Department of Horticulture, Michigan State University, East Lansing, MI 48824
}

\begin{abstract}
Stem elongation in commercial greenhouse production is controlled mainly by using synthetic plant growth retardants. Concern over the impact of these compounds on human health may limit their future availability (Bidinotto, 1990). The growth retardant daminozide (Alar) has been removed for use on food crops in the United States. The only growth retardant registered for controlling height of greenhouse crops in Germany is chlormequat (Ludolph, 1992). Emphasis, therefore, must be placed on developing effective nonchemical methods of controlling height in controlled-environment facilities.
\end{abstract}

One nonchemical plant height control method that has potential is suppressing elongation through touching (Biddington, 1986; Jaffe, 1973). Touching or shaking (Mitchell et al., 1975) a plant causes a thigmotropic response that reduces internode elongation via ethylene synthesis (Biddington, 1986; Jaffe, 1973; Latimer, 1991, 1993; Latimer and Thomas, 1991; Miller, 1991). Drawbacks to this method are the labor requirements and mechanical damage to plants (Latimer, 1991, 1993; Latimer and Thomas, 1991).

Another method of controlling stem elongation is by managing day and night temperatures (DT/NT) over a 24-h period (Erwin, 1991; Erwin and Heins, 1990; Erwin et al., 1989b; Heins and Erwin, 1990). Stem length increases as DT increases (Karlsson, 1986; Smith and Langhans, 1961; Tageras, 1979) and NT decreases (Karlsson, 1986; Tageras, 1979; Went, 1944, 1952, 1957). Interestingly, recent experimentation shows that morphological development in many plants is highly

Received for publication 20 May 1994. Accepted for publication 6 Dec. 1994. Minnesota Agricultural Experiment Station no. 21,128. We appreciate the assistance of Brian Kovanda, Joy Hind, Martin Stockton, Mark Smith, Wendy Cole, Tim Cefai, Roar Moe, Sharon Stroh, Debra Schwarze, Gerald Pierson, and Curt Cirhan. We thank Green Circle Growers and Andy Mast Greenhouses for donating plant material. We acknowledge the Minnesota Agricultural Experiment Station, the Michigan State Agricultural Experiment Station, the American Floral Endowment, the Bedding Plant Foundation, the F.C. Gloeckner Foundation, the Minnesota Commercial Flower Growers Association, the Ohio Florists Association, and the Western Michigan Bedding Plant Association for their financial support of the research presented in this article. The cost of publishing this paper was defrayed in part by the payment of page charges. Under postal regulations, this paper therefore must be hereby marked advertisement solely to indicate this fact. correlated with the difference between DT and NT (DIF) rather than the actual DT/NT under which plants are grown when temperatures range from 10 to 26C (Erwin, 1991; Erwin et al., 1989b; Moe and Heins, 1990; Moe et al., 1991). DIF, as defined in this work (DIF = DT - NT), quantifies how temperature affects stem elongation (Erwin et al., 1989b; Heins and Erwin, 1990, 1991). Subsequent research identified periods within the photoperiod, or scotoperiod (night period), when stem elongation was particularly sensitive to temperature fluctuations (Erwin, 1991; Erwin et al., 1989a).

The effect of diurnal temperature fluctuations on plant morphology was defined as thermomorphogenesis in these studies (Erwin et al., 1989b). This term was derived from the Greek derivatives therme, meaning heat; morphos, the quality of form; and gignesthai, to be born; hence, thermomorphogenesis is the effect of temperature on plant morphogenesis and is consistent with the term photomorphogenesis, which defines light effects on plant morphology.

Light quality, irradiance, and photoperiod interact with diurnal temperature fluctuations to affect stem elongation (Erwin, 1991, Erwin et al., 1992b; Moe et al., 1991). Stem elongation responses to diurnal temperature fluctuations can be enhanced or eliminated, depending on the light environment under which plants are grown (Erwin, 1991; Erwin et al., 1992b).

The physiological basis for the effects of diurnal temperature fluctuations on stem elongation is not understood. Some evidence suggests gibberellin (GA) involvement (Erwin, 1991; Erwin et al., 1989b; Moe et al., 1991; Pinthus and Meiri, 1979; Zieslin and Tsujita, 1988). However, other factors such as turgor, cell wall extensibility, and phytochrome photoequilibria or cycling appear to interact with DIF to affect stem elongation (Erwin, 1991; Erwin et al., 1992b; Lecharny et al., 1985; Moe and Heins, 1990).

Manipulating DT/NT is used extensively to control stem elongation in U.S. (Roberts, 1991) and European greenhouse industries. DT/NT manipulation is also being used to control elongation in tissue culture facilities in Japan (Kozai et al., 1992) and in controlledenvironment chambers at the National Aeronautics and Space Administration (M. Bates, personal communication).

Although the DIF concept and its use for controlling height in controlled environments was introduced only 9 years ago, considerable research on DIF has been conducted (Blacquière and Bakker, 1992; Moe and Mortensen, 1992). The objective of this re- view is to summarize recent research results on how diurnal temperature fluctuations affect stem and leaf development.

\section{STEM ELONGATION}

DT/NT effects on stem elongation. Went $(1944,1952,1957)$ showed that stem elongation was affected by DT and NT. Lycopersicon esculentum L. (tomato) stem length increased as DT increased and NT decreased (Went, 1944). Similar stem elongation responses to DT and NT were observed on Fuchsia $\times$ hybridaHort. ex Vilm. (fuchsia) (Tageras, 1979), Triticum aestivum L. (wheat) (Pinthus and Meiri, 1979), Dendranthema grandiflorum Ramat.(Kitamura)(chrysanthemum)(Karlsson, 1986; Karlsson et al., 1989), Campanula isophylla Moretti. (campanula) (Moe et al., 1991), and Lilium longiflorum Thunb. (lily) (Erwin and Heins, 1990; Erwin et al., 1989b; Smith and Langhans, 1961) (Fig. 1).

Erwin et al. (1989b) showed that the effects of temperature on Lilium stem length could best be described by the relationship between DT and NT, rather than by independent responses to DT or NT, with temperatures between 10 and $26 \mathrm{C}$ (Fig. 2). Internode length of Lilium increased as DIF increased from -16 to +16C (Fig. 3). Similar relationships between DIF and stem elongation were reported on Dendranthema (Karlsson et al, 1989; Ludolph, 1992), Euphorbia pulcherrima Willd. ex Klotzsch (Berghage, 1989; Berghage and Heins, 1990), Xanthium pensylvanicum L. (Erwin, 1991), Streptocarpus nobilis C.B. Clarke. (Erwin, 1991), Campanula (Moe et al., 1991), Fuchsia (Erwin et al., 1991b), Begonia $\times$ tuberhybrida Voss. and Kalanchoe blossfeldiana Poelln. (Jacobsen et al., 1991), Ribes sativum Syme. (unpublished data), and Solanum tuberosum L. (Kozai et al., 1992). The only plant species observed that do not respond to DIF are spring bulb crops or ephemerals (Tulipa $\times$ hybrida L., Narcissus pseudonarcissus L., and Hyacinthus orientalis L.) (Heins and Erwin, 1990).

Although original research by Went (1957) suggested that stem height was primarily influenced by DT, measuring internode lengths from his published photographic plates of Pisum sativum L. (pea) plants (plate IX) showed that internode length of Pisum was strongly correlated with DIF $\left(r^{2}=0.72\right)$.

Stem elongation of some species has an optimal temperature and a response to DIF. For instance, E. pulcherrima stem elongation is affected by DIF and the actual DT or NT. For example, Euphorbiainternode length increased 

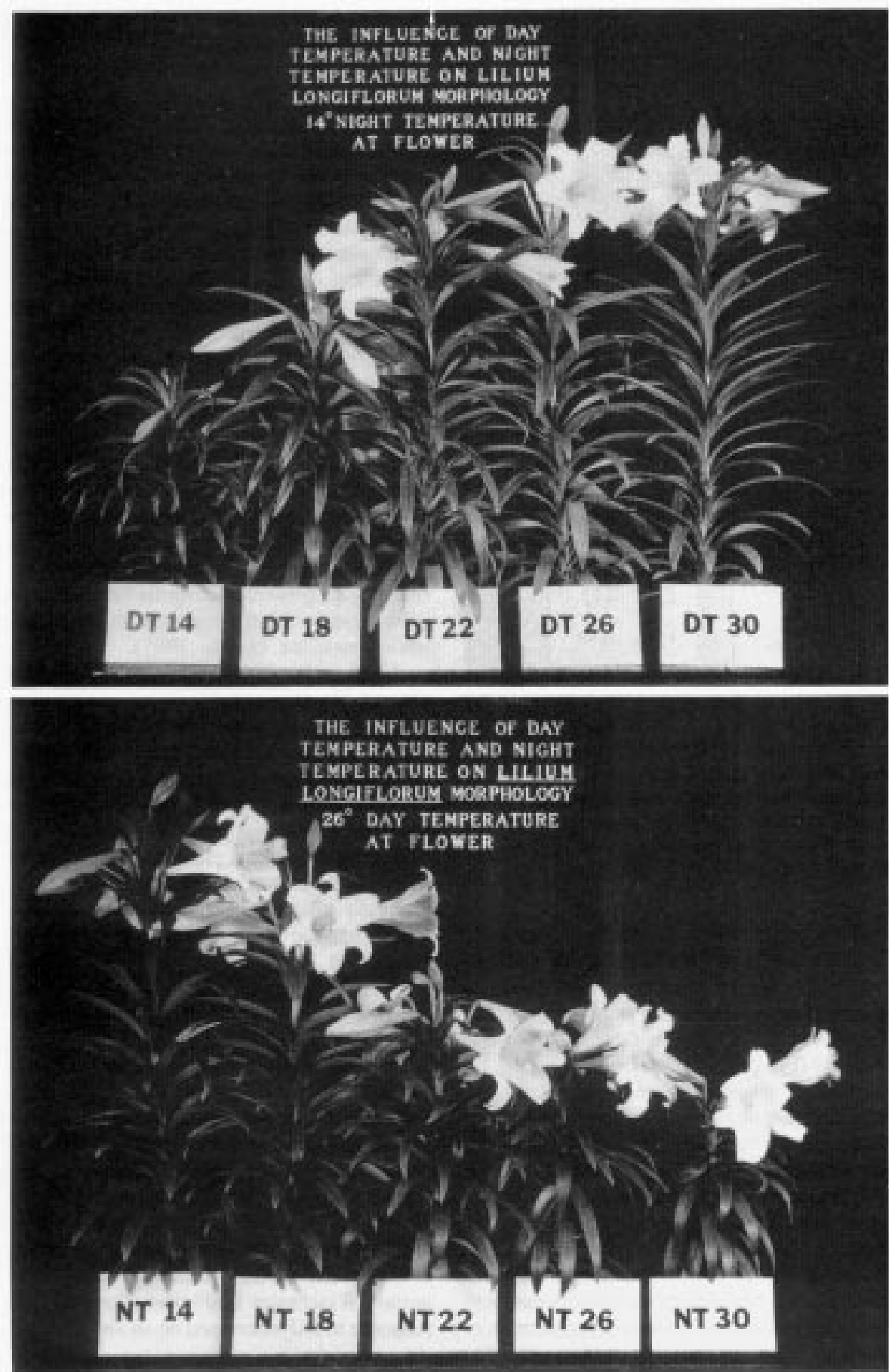

Fig. 1. The effect of increasing day temperature (DT) (top) and increasing night temperature (NT) (bottom) on the height of Lilium longiflorum 'Nellie White' at anthesis. Plants grown at higher average daily temperatures flowered earlier than plants grown at lower average daily temperatures. As plants grown at higher average daily temperatures reached anthesis, they were placed in a cooler (4C) until plants grown at lower temperatures reached anthesis. Stem elongation did not occur in the cooler. When all plants had reached anthesis, the photograph was taken. Internode count was similar for all plants (Erwin et al., 1989b)

as DT or NT approached 24C, then decreased when either DT or NT increased from 24 to 30C (Berghage and Heins, 1990). Similarly, Impatiens hawkeri Bull. internode length increased from 10 to $32 \mathrm{~mm}$ as DT and NT (0C DIF) approached $26 \mathrm{C}$, then decreased from 32 to $30 \mathrm{~mm}$ as DT and NT increased from 26 to 30C (Erwin et al., 1992a). Stem elongation of Petunia $\times$ hybrida Hort. and some varieties of Pelargonium $\times$ hortorum L.H. Bailey has an vary among species or cultivars. Lycopersicon, Zea mays L. (corn), and Cucumis sativus L. (cucumber) show a strong response to DIF. In contrast, Pisum and Phaseolus vulgaris L. (bean) show little response to DIF (Erwin et al., 1994a) (Table 1). Cucurbita melopepo var. pepo C. (squash) and Citrullus lanatus Thunb. (watermelon) show an intermediate response to DIF

Euphorbia pulcherrima cultivars differ in their response to DIF (Moe et al., 1992a, 1992b). Euphorbia 'Lilo' showed relatively little response to DIF; in contrast, 'Star Light' was strongly responsive to DIF.

Stem vs. root temperature effects on stem elongation responses to DIF. Preliminary experiments suggested that the temperature of the elongating region of a stem and not the root temperature was critical in eliciting DIF effects on stem elongation in Dendranthema (unpublished data). In contrast, Lecharny et al. (1985) showed that Chenopodium rubrum $\mathrm{L}$. stem elongation was affected when root temperature was altered independently of shoot temperature. Their data suggested that shoot turgor pressure (associated with root temperature) may play a partial role in determining temperature effects on stem elongation.

Differential sensitivity of stem elongation to temperature within the photoperiod. Plant stem elongation is not constant during a 24-h DT/NT cycle (Erwin and Heins, 1988; Erwin et al., 1992b; Lecharny et al., 1985; Tutty et al., 1992, 1994; Went, 1952). Stem elongation rate decreases from the start to the end of the photoperiod and increases from the start to the end of the scotoperiod (Fig. 4). The rate of stem elongation is greatest at the end of the scotoperiod and the beginning of the photoperiod (Erwin and Heins, 1988; Erwin et al., 1992b; Lecharny et al., 1985; Tutty et al., 1994; Went, 1952).

The relative amounts of stem elongation that occur during the photoperiod and scotoperiod appear to be influenced by species and night-interruption lighting. Dendranthema grandiflora 'Bright Golden Anne' elongated nearly equally during the day and night when plants received night-interruption lighting to inhibit flowering (J.E. Erwin, personal observation). However, Dendranthema elongation was higher during the night than the day when plants did not receive night-interruption lighting to induce flowering ( $4.17 \mathrm{vs.} 2.25 \mathrm{~mm} / 24$ $\mathrm{h}$ period). In contrast, Fuchsia $\times$ hybrida 'Dollar Princess' plants elongated more during the night than day when they received a night interruption to induce flowering. These data suggest that flower induction may influence stem elongatation during a 24-h day/night cycle (J.E. Erwin, personal observation).

The question arises as to whether stem elongation is differentially sensitive to temperature at different times during a day/night cycle. Stem elongation appears to be most sensitive to temperature fluctuations during the first 2 to $4 \mathrm{~h}$ of the photoperiod in Lilium, Salvia, and Petunia (Erwin et al., 1989a; Grindal and Moe, 1994; Heins and Erwin, 1990, 1991; Moe et al., 1992b) (Fig. 5a) when grown with an 8-h photoperiod. Dropping 


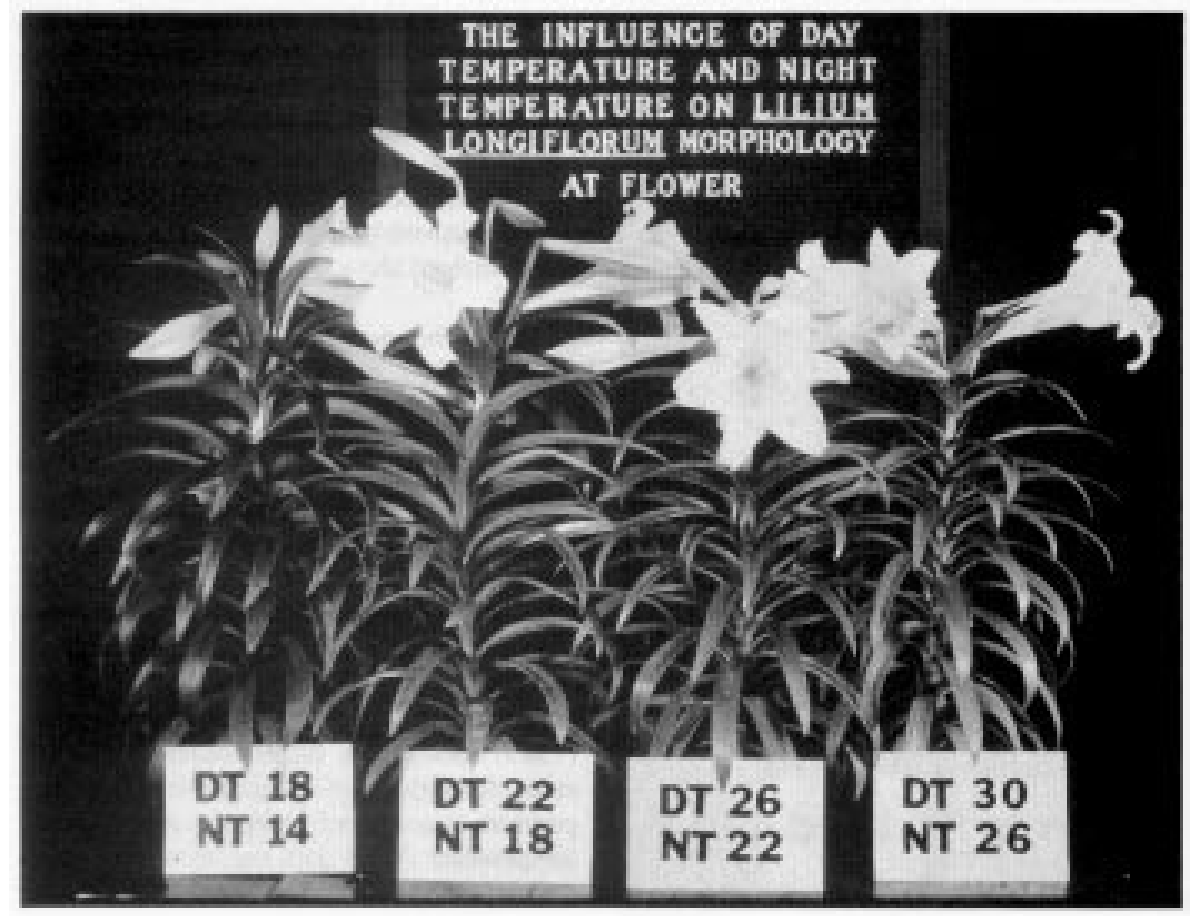

Fig. 2. Appearance of Lilium longiflorum 'Nellie White' at anthesis when grown under four day and night temperature (DT/NT) regimes (DT $-\mathrm{NT}=\mathrm{DIF})$, with DT 4C lower $(-4 \mathrm{C}$ DIF) than NT across regimes, i.e., equal DT/NT relationship. Plants grown at higher average daily temperatures flowered earlier than plants grown at lower average daily temperatures. As plants grown at higher average daily temperatures reached anthesis, they were placed in a cooler (4C) until plants grown at lower temperatures reached anthesis. Stem elongation did not occur in the cooler. When all plants had reached anthesis, the photograph was taken. Internode count was similar for all plants (Erwin et al., 1989b).

temperatures during the first $2 \mathrm{~h}$ of the photoperiod to below the NT was almost as effective (expressed as a percentage) in inhibiting daily stem elongation as dropping temperatures to below the NT during the entire photoperiod. The longer temperatures are reduced during the photoperiod, the greater the inhibition of stem elongation (Ludolph, 1992; Ueber

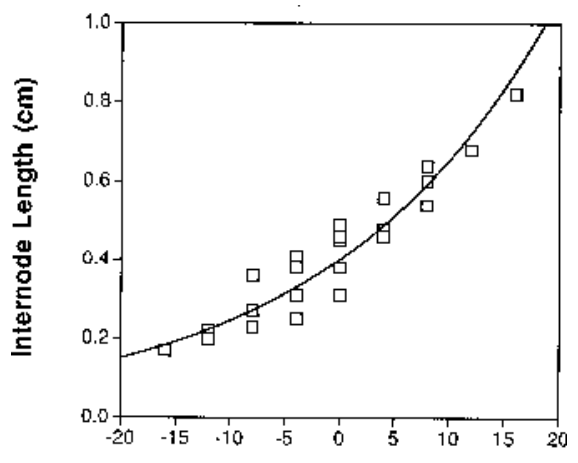

Difference Between DT and NT (oC)

Fig. 3. Relationship between Lilium longiflorum 'Nellie White' internode length at anthesis and day and night temperature (DT/NT) difference (DIF). Squares represent mean plant heights for each treatment. The solid line represents the regression function $1.4860 \times \mathrm{DIF}-0.0416 \times \mathrm{DT}$ $\times \mathrm{NT}+1.9139 \times$ AVG TEMP $+25.661\left(r^{2}=\right.$ $0.84)$. The regression line also represents the effect of DT and NT by NT interaction and the effect of average temperature on final height. Internode count was similar for all plants (Erwin et al., 1989b). crop species (within a row) (Erwin et al., 1994a).

${ }^{\mathrm{z} N u m e r a l s ~ r e p r e s e n t ~ t r e a t m e n t ~ m e a n s ~ a n d ~ S D ~ a b o u t ~ t h e ~ m e a n . ~}$ gation as a temperature increase at the beginning of the photoperiod.

Fluctuating temperature at different times of the night had little or no effect on Dendranthema stem elongation when grown with an 8$\mathrm{h}$ photoperiod (Erwin, 1991). Increasing temperature at the beginning or end of the night did not affect Salvia or Petunia (Erwin, 1991) final internode length. In contrast, Jensen (1993) showed final plant height on Dendranthema and Euphorbia decreased when temperature was increased at different times of the scotoperiod (-DIF treatment), but the decrease in final plant height was not always obvious since the number of internodes increased in some experimental treatments due to a delay in flower initiation.

In contrast, Mortensen and Moe (1992) reported that high temperature at the end of the photoperiod increased height in some species and inhibited elongation in others. A similar increase in internode length following an increase in temperature during the first $2 \mathrm{~h}$ of the scotoperiod was also reported on Impatiens wallerana Hook. (Erwin, 1991).

Changes in sensitivity to DIF during development. The effect of DIF on stem elongation is greatest when a plant is elongating most rapidly (Berghage, 1989; Heins and Erwin, 1990). Therefore, determinate plants are most sensitive to DIF during the rapid elongation phase of their development compared to the beginning or ending phase of development when plants are not elongating rapidly. Indeterminate plants appear equally sensitive to DIF throughout development (Heins and Erwin, 1990).

Interaction between DIF and photoperiod. Photoperiod interacts with DIF to affect stem elongation (Berghage et al., 1991a; Erwin et al., 1991b, 1992b). In general, plant stem elongation responses to DIF decrease as photoperiod length increases. The reduced response to DIF as photoperiod length increases occurs whether photoperiod is extended by night-interruption lighting (Erwin et al., 1991b) (Fig. 6) or day-extension lighting on Fuchsia (R.D. Berghage, personal communication; Erwin et al., 1992b). Similarly, Antirrinum majus 'Winchester Red' stem elongation in response to DIF decreased on an absolute and

Table 1. Effect of day and night temperature (DT/NT) difference (DIF) on the length of the third internode of Zea mays 'Snow Belle', Pisum sativum 'Mars', Citrullus lanatus 'Crimson Sweet', Phaseolus vulgaris 'Blue Lake', Lycopersicon esculentum 'Sunny', and Cucumis sativus grown under three environments: 17C DT/23C NT (-6C DIF), 20C DT/20C NT (0C DIF), and 23C DT/17C NT (+6C DIF). Irradiance was maintained at $350 \mu \mathrm{mol} \cdot \mathrm{m}^{-2} \cdot \mathrm{s}^{-1}$. Photoperiod and thermoperiod lengths were $12 \mathrm{~h}$. The variable $b_{0}$ was determined by regressing internode length against DIF in a linear equation $a+b_{0} x=y$, where $\mathrm{a}=$ constant, $\mathrm{b}_{0}=$ slope, $\mathrm{x}=\mathrm{DIF}$, and $\mathrm{y}=$ internode length. Significance of the response to DIF was determined through mean separation using Tukey's tests of significance (alpha $=0.05)$ within each

\begin{tabular}{llllrc}
\hline & \multicolumn{3}{c}{ Third internode length $(\mathrm{cm})$} & & \\
\cline { 2 - 5 } Crop & -6 C DIF & 0C DIF & +6 C DIF & $\mathrm{b}_{0}$ & Significance \\
\hline Zea mays & $1.7 \pm 0.4^{\mathrm{z}}$ & $3.9 \pm 1.5$ & $5.5 \pm 0.8$ & 0.32 & $* * *$ \\
Pisum sativum & $2.4 \pm 0.3$ & $2.0 \pm 0.3$ & $2.3 \pm 0.2$ & -0.01 & NS \\
Citrullus lanatus & $0.4 \pm 0.1$ & $3.7 \pm 1.0$ & $2.5 \pm 0.6$ & 0.17 & $*$ \\
Phaseolus vulgaris & $3.6 \pm 0.6$ & $4.2 \pm 0.9$ & $4.8 \pm 0.8$ & 0.10 & $*$ \\
Lycopersicon esculentum & $2.0 \pm 0.3$ & $2.6 \pm 0.3$ & $4.6 \pm 0.9$ & 0.22 & $* * *$ \\
Cucumis sativus & $4.7 \pm 0.4$ & $7.6 \pm 1.1$ & $7.7 \pm 1.4$ & 0.25 & $* *$ \\
\hline
\end{tabular}

Ns, ${ }^{* * * * * * * *}$ Nonsignificant or significant at $P \leq 0.05,0.01$, or 0.001 , respectively. 


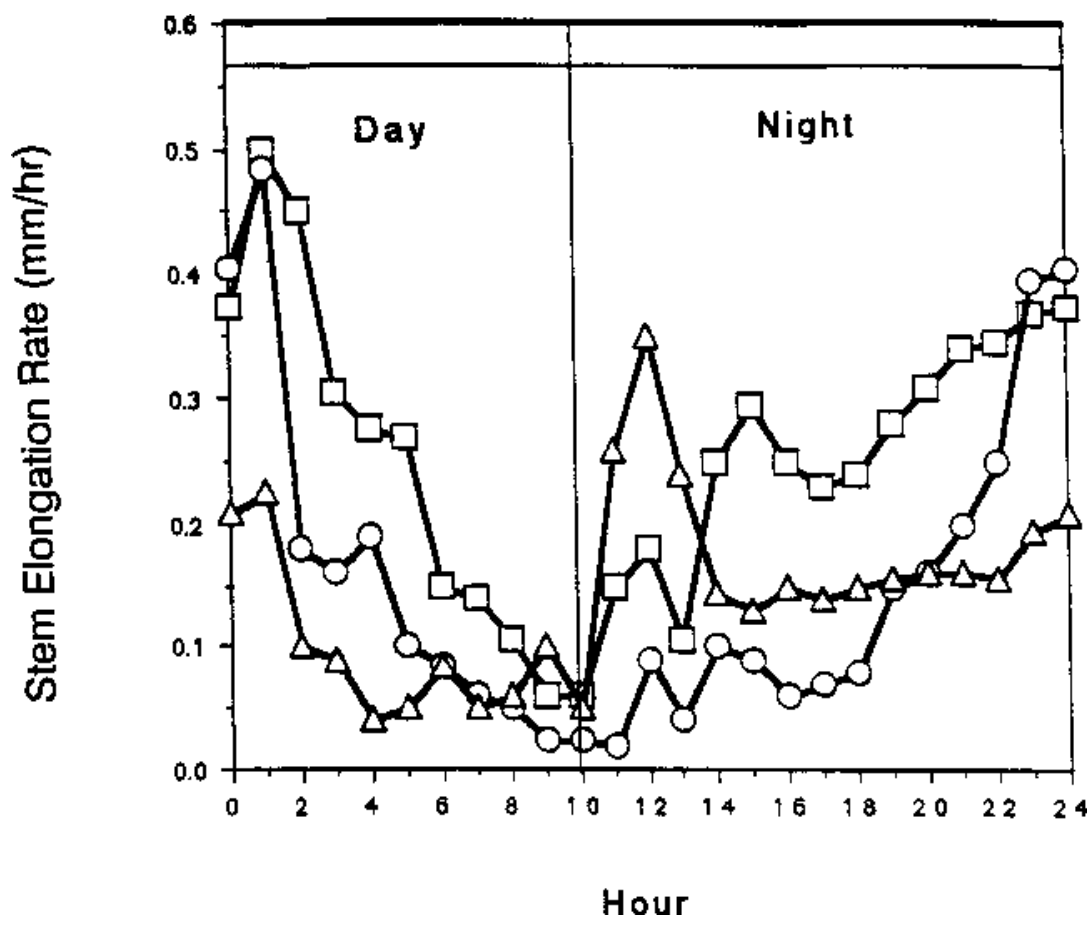

Fig. 4. The effect of day and night temperature (DT/NT) difference (DIF) on the rate of Dendranthema grandiflora 'Bright Golden Anne' stem elongation. Data presented were collected every 5 min for 3 days. Hourly means were then calculated. Data were collected with an angular displacement transducer connected to a computer. The system had a resolution of $2 \mu \mathrm{m} / 5 \mathrm{~min}$. Squares, circles, and triangles represent hourly treatment means of the stem elongation rate of plants grown with a higher day temperature (DT) than night temperature (NT) (23/17C DT/NT), equal DT and NT (20/20C DT/NT), and lower DT than NT (17/23C DT/NT), respectively (Erwin and Heins, 1990; Erwin et al., 1992b).

percentage basis as photoperiod length increased from 8 to $16 \mathrm{~h}$ (unpublished data).

Interaction between irradiance and light quality and DIF. Irradiance interacts with DIF to affect stem elongation (Erwin et al., 1992b; Ludolph, 1992). Stem elongation responses to DIF increase as irradiance levels increase (Erwin et al., 1992b, Heins and Erwin, 1990; Ludolph, 1992; J. Myster and R. Moe, personal communication; unpublished data). The basis for the increase in the response of stem elongation to DIF as irradiance increases is not understood.

Light quality interacts with DIF to affect stem elongation (Erwin, 1991; Moe and Heins, 1990; Moe et al., 1991). Specifically, there is an interaction between phytochrome photoequilibria and DIF on stem elongation. Continuous far-red light during the night overcomes the reduction in stem elongation on Campanula (Table 2) (Moe et al., 1991) and Fuchsia (Erwin, 1991) grown in a -DIF environment compared to a +DIF environment. Continuous red light during the night enhanced the inhibition of stem elongation by a -DIF environment in Campanula (Moe et al., 1991). In contrast, daylight supplemented with 5 to $10 \mu \mathrm{mol} \cdot \mathrm{m}^{-2} \cdot \mathrm{s}^{-1}$ of red light enhanced the response of Fuchsia stem elongation to a -DIF environment (unpublished data). Based on these data, we hypothesize that phytochrome photoequilibria or cycling and DIF effect stem elongation using a similar pathway.

Effects of blue light on plant responses to DIF are unknown. However, preliminary data suggest that supplemental blue lighting during the day reduces stem elongation in general but does not interact with DIF to affect stem elongation (J.E. Erwin, personal observation).

Other experiments on the effects of DIF on stem elongation have led to different results when plants were grown in greenhouses under natural daylight and photoperiods. For instance, experimentation in Europe showed less response of many plant species than the response of those same species in the United States (Hendricks, 1991; Langton et al., 1992; Vogelezang et al., 1992a). Similarly, experimentation in Europe to determine how reducing temperature during the beginning of the photoperiod affects stem elongation has led to different results in different locations (Vogelezang et al., 1992b). These differences in DIF based on location are probably related to lower irradiance levels or longer photoperiods than those present during experiments conducted in the United States. Reduced irradiance and extended photoperiod reduce the response of stem elongation to DIF (see above).

\section{LEAF EXPANSION}

DT/NT effects on leaf expansion. Temperature strongly influences leaf expansion (Dale, 1964, 1965; Milthorpe, 1959). Dale (1964) showed that Phaseolus leaf expansion was greatest when DT and NT were constant, i.e., a 0C DIF. Reexamining Dale's data showed that this conclusion was based on several environmental treatments that contained either a 30C DT or NT. Based on Dale's conclusions, leaf expansion was reduced at 30C. Therefore, conclusions relating temperature effects on leaf expansion based on treatments at 30C may be misleading. If Dale's data from environments containing a 30C DT or NT are eliminated, Phaseolus leaf area increased as DIF increased. A positive correlation between DIF and leaf area has also been noted on Fuchsia $\left(r^{2}=0.81\right)$ (Erwin et al., 1991b) (Fig. 7a). Similarly, leaf area increased on tissue-cultured Solanum as DIF increased (Kozai et al., 1992). In contrast to the mentioned species, Lilium leaf length was affected by NT only (Fig. 7b) (Erwin et al., 1989b).

Some plant species appear to have the greatest leaf expansion when plants are grown with constant temperatures (OC DIF); i.e., any temperature fluctuation reduced leaf expansion. For instance, Cucumis expansion was greatest when plants were grown at constant 20C (Milthorpe, 1959). Recent research on Cucumis showed that leaf expansion was greatest when plants were grown at constant 23C (unpublished data).

\section{LEAF ORIENTATION}

Leaf orientation, defined as the angle of the leaf relative to a line perpendicular (normal) to the stem axis, is affected by DIF. Leaf orientation increased as DIF increased from -16 to $16 \mathrm{C}$ on Lilium (Erwin et al., 1989b). Therefore, the position of the leaf becomes more upright; i.e., leaf orientation increases as DIF becomes more positive (Fig. 8). Similar results were reported by Moe and Heins (1990) on several other crop species.

\section{LEAF CHLOROPHYLL CONTENT}

Leaf chlorophyll content is affected by DIF and the average daily temperature under which plants are grown (Berghage et al., 1991a; Erwin, 1991; Erwin and Pierson, 1992; Erwin et al., 1991a). Total chlorophyll per unit area and per gram dry weight increased as DIF increased. The chlorophyll $a$ to chlorophyll $b$ ratio calculated on a per-unit-area and a per-gram-dry weight basis increased as DIF decreased from +10 to $-10 \mathrm{C}$ on Fuchsia and Dendranthema (Fig. 9) (Erwin et al., 1991a). In addition, total chlorophyll $(a+b+p)$ and the chlorophyll $a$ to chlorophyll $b$ ratio decreased as the average daily temperature under which plants were grown increased. Often the reduced chlorophyll content resulting from altering DIF is temporary (Heins and Erwin, 1990).

\section{LEAF NUTRIENT COMPOSITION}

Relatively few data about how DIF affects nutrient uptake are available. Calcium and $\mathrm{Mg}$ content in Euphorbia leaf tissue (percentage of dry matter) decreased as DIF increased (Berghage et al., 1991b). In contrast to Ca and $\mathrm{Mg}, \mathrm{N}$ and $\mathrm{P}$ decreased and $\mathrm{K}$ increased as the average daily temperature under which plants 
were grown increased. Iron content was a function of NT only, whereas Fe content decreased as NT increased.

\section{ANATOMICAL BASIS FOR DIF RESPONSES}

Observations on Lilium stem segments from plants grown under different DT/NT regimes showed that plant stem elongation and leaf expansion responses to DIF were due to differences in cellular elongation and not division (Erwin et al., 1991c, 1994b) (Fig. 10). Cell elongation increased as DIF increased, while cell width was unaffected by DIF. The response of cell elongation, but not division, to DIF was observed on stem parenchyma and epidermal cells. Leaf epidermal cell elonga-
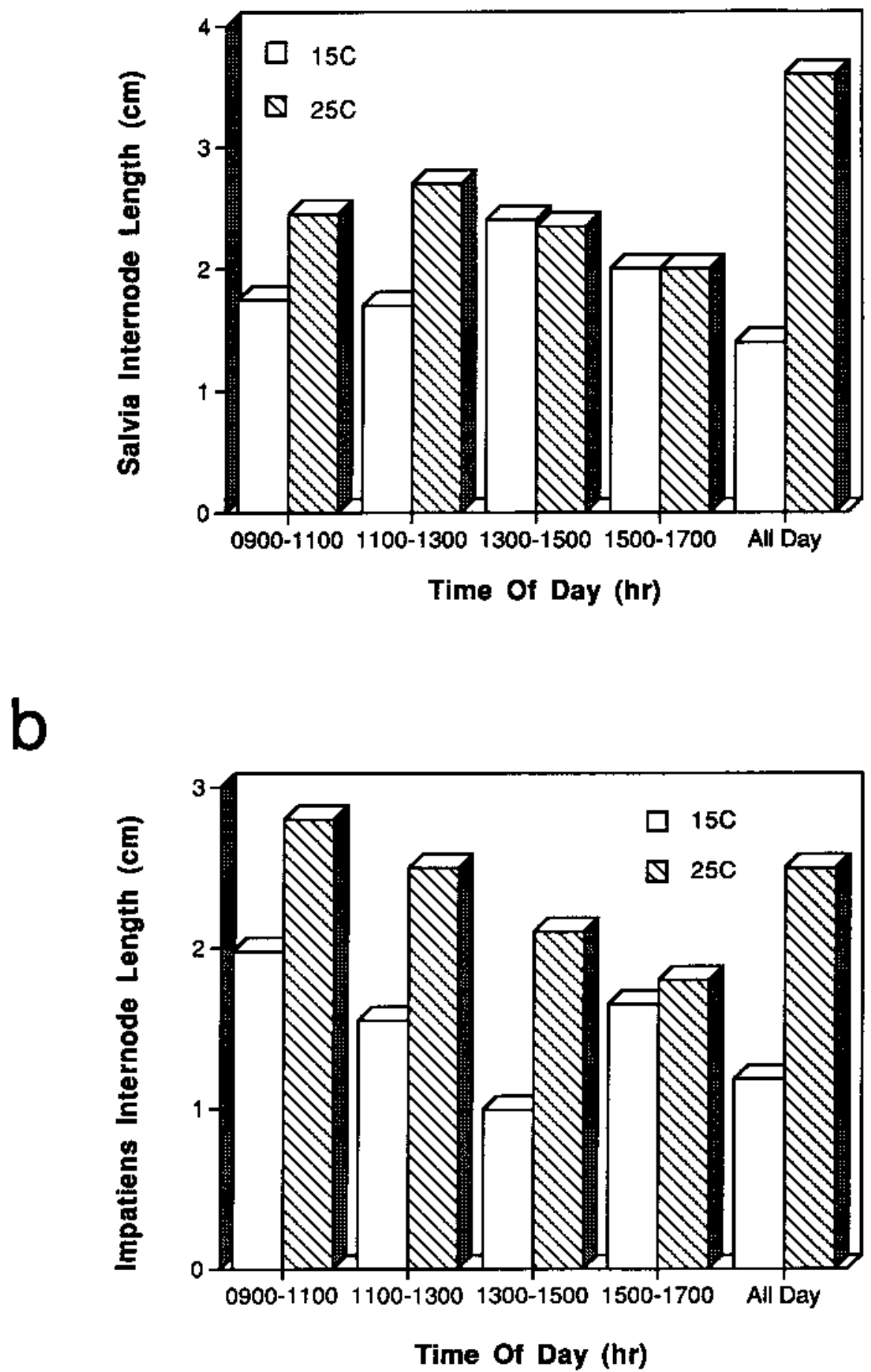

Fig. 5. The effect of day and night temperature (DT/NT) difference (DIF) on (a) Salvia splendens and (b) Impatiens wallerana (Erwin, 1991). All plants were grown at constant 20C. Photoperiod and thermoperiod were initiated simultaneously at $0900 \mathrm{HR}$. Plants were moved to either a 15 or $25 \mathrm{C}$ environment at the designated times. Control treatments represent $15 / 20$ or $25 / 20$ day/night temperature regimes, where treatment temperatures were delivered all day (Erwin, 1991).

tion was also affected by DIF, but cell division was not.

\section{CARBON PARTITIONING}

As with nutrient uptake, relatively few data have been collected on DIF effects on carbon partitioning. Karlsson and Heins (1992) showed that total plant dry weight (stems, leaves, flowers, and roots) increased as DT and NT decreased from 30 to $20 \mathrm{C}$, respectively, on Dendranthema. In contrast, total shoot dry weight (stems, leaves, and flowers only) was highest when Fuchsia and Impatiens plants were grown in a $25 / 15 \mathrm{C}$ and $25 /$ 20C DT/NT environment, respectively (Erwin et al., 1992a). Kozai et al. (1992) showed that Solanum plantlet dry weight was unaffected by DIF in tissue culture (DIF levels varying from -10 to $+10 \mathrm{C}$ ).

Impatiens hawkeri 'Mimas' and Fuchsia $\times$ hybrida 'Dollar Princess' stem dry weight increased linearly as DIF increased from -10 to 15C (Erwin and Heins, 1991; Erwin et al., 1992a) (Fig. 11a). Percentage partitioning of dry weight into stems vs. flowers or leaves depended primarily on DT (Fig. 11b). Partitioning to Dendranthema roots decreased as DT increased, and partitioning to stems increased as DIF increased (Karlsson and Heins, 1992).

In contrast to stem dry weight, Impatiens and Fuchsia leaf and flower dry weight had temperature optima (Erwin and Heins, 1991; Erwin et al., 1991b, 1992a). The optimal temperature for dry weight partitioning to leaves and flowers was 24 and 20C, respectively, for Impatiens and fuchsia. In contrast, partitioning to Dendranthema flowers was not strongly correlated with DT, NT, or DIF (Karlsson and Heins, 1992).

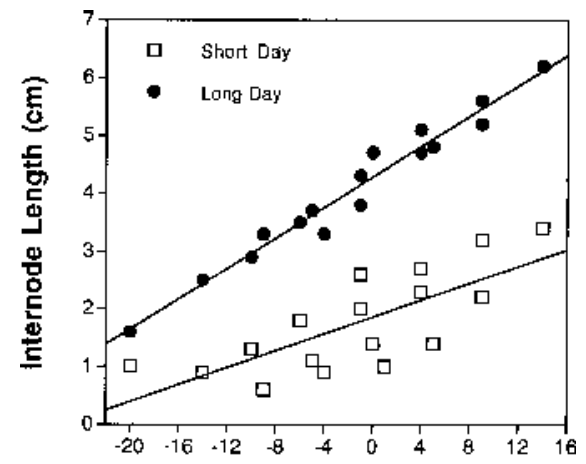

Difference Between DT and NT $\left({ }^{\circ} \mathrm{C}\right)$

Fig. 6. Effect of day and night temperature (DT/NT) difference (DIF) on internode length of Fuchsia Xhybrida 'Dollar Princess' plants grown under long days (LDs) (9-h, 15-min photoperiod plus 4$\mathrm{h}$ night interruption using incandescent lamps at $\left.2 \mu \mathrm{mol} \cdot \mathrm{m}^{-2} \cdot \mathrm{s}^{-1}\right)$ and short days (SDs) $(9-\mathrm{h}, 15-\mathrm{min}$ photoperiod). Data were normalized across 1988 and 1989 experiments within photoperiod treatments. Regression function calculated from LD data was internode length $(\mathrm{cm})=4.727+(0.129$ $\times$ DIF) $\left(r^{2}=0.87\right)$, and from SD data was internode length $(\mathrm{cm})=1.871+(0.071 \times$ DIF $)$ $\left(r^{2}=0.64\right)$ (Erwin et al., 1991b) 
Table 2. Effects of day and night temperature (DT/NT) difference (DIF) and two light quality exposures as day-extension lighting with incandescent (INC) or fluorescent (FL) lamps on stem length and plant dry weight at visible bud (VB) and anthesis of Campanula isophylla 'Bla'. DT was applied during the 10h photoperiod at $89 \mu \mathrm{mol} \cdot \mathrm{m}^{-2} \cdot \mathrm{s}^{-1}$ supplied with FL lamps (TL 33). NT was provided during the dayextension period of $14 \mathrm{~h}$. Irradiance during the day-extension period was $0.58 \mathrm{~W} \cdot \mathrm{m}^{-2}(400-1000 \mathrm{~nm})$ with each light source. Since day-extension lighting occurred during the entire night period, plants were grown under continuous lighting. Dry weight data were collected 12 weeks after germination (Moe et al., 1991).

\begin{tabular}{lcccc}
\hline \hline DT/NT & \multicolumn{2}{c}{$\begin{array}{c}\text { Light source } \\
\text { for day extension }\end{array}$} & Stem length $(\mathrm{cm})$ & Dry \\
\cline { 3 - 5 }$\left({ }^{\circ} \mathrm{C}\right)$ & INC & $26.5 \mathrm{a}$ & Anthesis & wt $(\mathrm{g})$ \\
\hline $21 / 15 \mathrm{C}(+6 \mathrm{DIF})$ & FL & $20.5 \mathrm{~b}$ & $33.1 \mathrm{a}$ & $2.9 \mathrm{~b}$ \\
$21 / 15 \mathrm{C}(+6 \mathrm{DIF})$ & INC & $24.9 \mathrm{a}$ & $39.6 \mathrm{a}$ & $2.4 \mathrm{a}$ \\
$15 / 21 \mathrm{C}(-6 \mathrm{DIF})$ & FL & $14.4 \mathrm{c}$ & $24.1 \mathrm{c}$ & $3.8 \mathrm{c}$ \\
$15 / 21 \mathrm{C}(-6 \mathrm{DIF})$ & & & $3.0 \mathrm{~b}$ \\
\hline
\end{tabular}

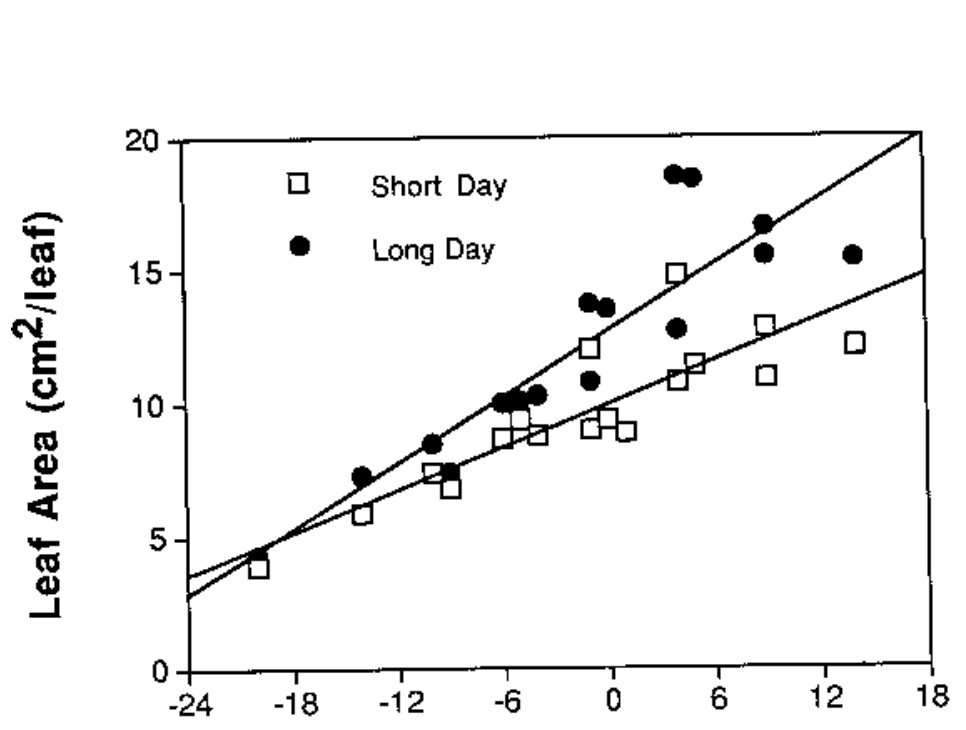

Difference Between DT and NT (OC)

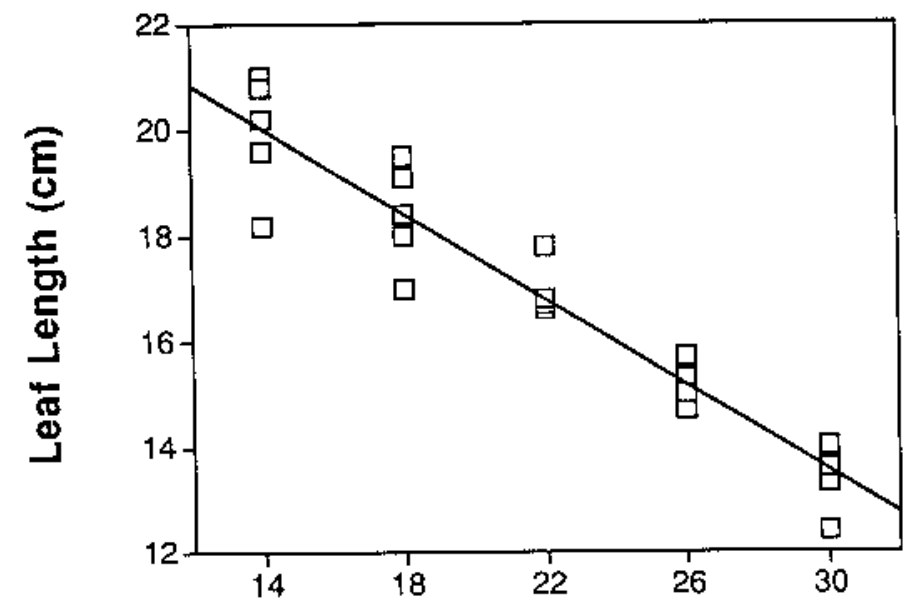

Night Temperature $\left({ }^{\circ} \mathrm{C}\right)$

Fig. 7. (a) The effect of day and night temperature (DT/NT) difference (DIF) on leaf area of Fuchsia xhybrida 'Dollar Princess' plants grown under long days (LDs) (9-h, 15-min photoperiod plus 4-h night interruption using incandescent lamps at an irradiance of $2 \mu \mathrm{mol} \cdot \mathrm{m}^{-2} \cdot \mathrm{s}^{-1}$ ) and short days (SDs) $(9-\mathrm{h}, 15$ min photoperiod). Data were normalized across time within each photoperiod. Regression function calculated from LD data was leaf area $\left(\mathrm{cm}^{2}\right)=14.99+(0.52 \times$ DIF $)\left(r^{2}=0.81\right)$, and from SD data was leaf area $\left(\mathrm{cm}^{2}\right)=13.10+(0.40 \times$ DIF $)\left(r^{2}=0.66\right)($ Erwin et al., 1991b). (b) The effect of NT on Lilium longiflorum 'Nellie White' leaf length $(\mathrm{cm})=25.71-0.41 \times \mathrm{NT}\left({ }^{\circ} \mathrm{C}\right)\left(r^{2}=0.91\right)($ Erwin et al., 1991b).

\section{PHYSIOLOGICAL BASIS FOR DIF RESPONSES}

Exogenous application of growth regulators. Stem elongation responses to DIF may be associated with alterations in bioactive GA levels or tissue sensitivity to GA (Erwin et al., 1989b, 1992b; Moe et al., 1991; Pinthus and Meiri, 1979; Zieslin and Tsujita, 1988). Applying $\mathrm{GA}_{3}$ to Triticum plants grown with a cooler day than night (-DIF) resulted in plants that resembled those grown with a warmer day than night (+DIF); i.e., $\mathrm{GA}_{3}$ overcame the DIF effect (Pinthus and Meiri, 1979). Similarly, applying $\mathrm{GA}_{4+7}$ to Lilium bulbs before planting overcame subsequent inhibition of stem elongation by a -DIF environment (Zieslin and Tsujita, 1988). Moe et al. (1991) and Erwin and Pierson (1992) showed that spray applications of $\mathrm{GA}_{3}$ overcame inhibition of Campanula and Lycopersicon internode elongation, respectively, when plants were grown in a-DIF environment. GA 1 overcame inhibition of Antirrinum stem elongation by a -DIF environment (unpublished data).

In contrast to data on exogenous application of GA, applying the GA biosynthesis inhibitor ancymidol resulted in a greater percentage decrease in internode length of + DIFgrown than -DIF-grown Lilium plants (Table 3) (Erwin et al., 1989b).

Light and temperature affect the ability of tissue to respond to GA. Early research by Lockhart (1958) clearly demonstrated that dwarfism in Phaseolus 'Alaska' was apparent only when plants were grown in the light. Pinthus and Meiri (1979) demonstrated that genotypic differences in height were conspicuous among genetic dwarf Rht mutants of Triticum when plants were grown at constant $25 \mathrm{C}$, but were only slight or inconspicuous when plants were grown at constant $11 \mathrm{C}$. Interestingly, the increase in the endogenous level of $\mathrm{GA}_{1}$ was much greater, i.e., 3-fold, 6-fold, and 9-fold, on the Rht $1, R h t 2$, and $R h t 1+2$ geno-

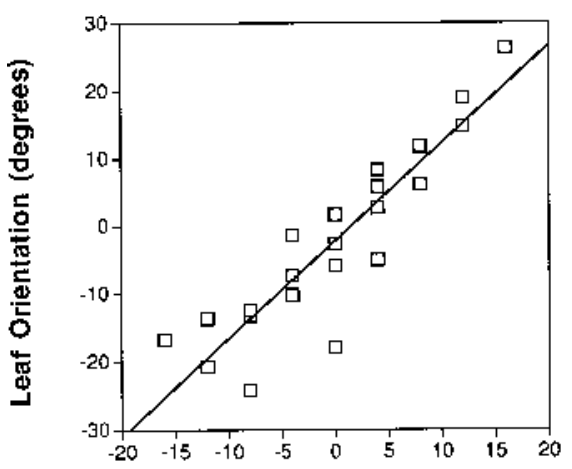

Difference Between DT and NT (oC)

Fig. 8. The effect of day and night temperature (DT/ NT) difference(DIF) on Lilium longiflorum 'Nellie White' leaf orientation, where leaf orientation = $-2.35+1.45 \times \mathrm{DIF}\left(r^{2}=0.82\right)$. Leaf orientation was defined as the angle of a leaf relative to a line normal to the plant stem axis. A positive angle indicated an upright leaf orientation. A negative angle indicated a downward leaf orientation (Erwin et al., 1989b). 
types, respectively, than the 1.6-fold increase in $\mathrm{GA}_{1}$ in the wild-type when temperature was 25 rather than 10C. Apparently, the response of Triticum tissue to endogenous or applied GA was restricted by the upper limits of GA responsiveness set by the different $R h t$ alleles.
Singh and Paleg (1984, 1985a, 1985b) demonstrated that low temperatures $(5 \mathrm{C})$ increased the sensitivity of Triticum aleurone layers to $\mathrm{GA}_{3}$ compared to high temperatures (30C). The authors hypothesized that the change in Triticum aleurone layer sensitivity
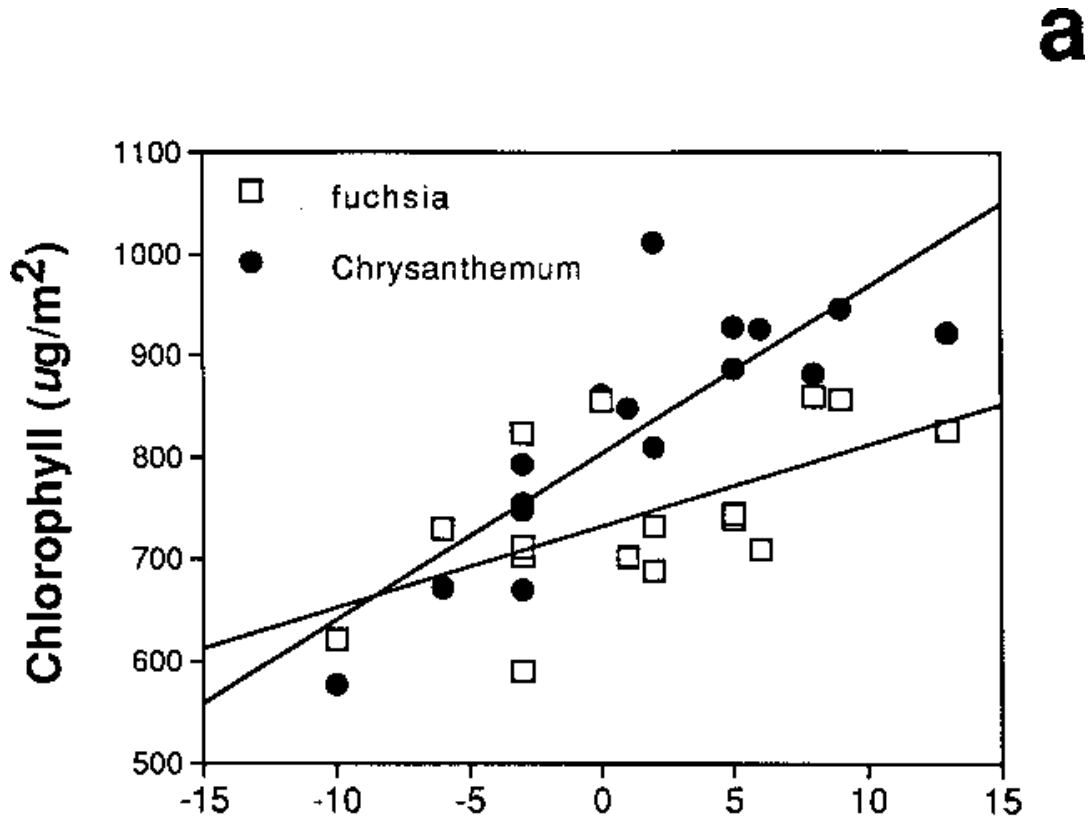

Difference Between DT and NT $\left({ }^{\circ} \mathrm{C}\right)$

b

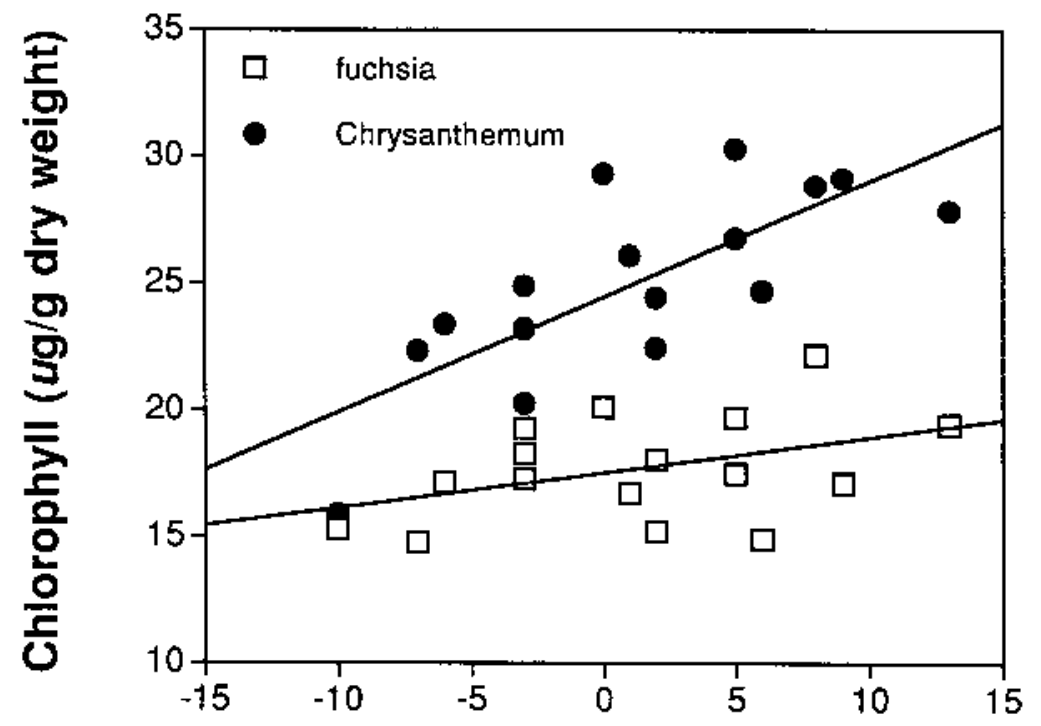

Difference Between DT and NT $\left({ }^{\circ} \mathrm{C}\right)$

Fig. 9. The effect of day and night temperature (DT/NT) difference (DIF) on total chlorophyll content of Dendranthema grandiflora and Fuchsia $\times$ hybrida expressed on (a) a per-unit area [equations for fuchsia and chrysanthemum, where chlorophyll $\left(\mu \mathrm{g} \cdot \mathrm{m}^{-2}\right)=732+7.99 \times \mathrm{DIF}\left(r^{2}=0.35\right)$ and $804+16.33 \times \mathrm{DIF}$ $\left(r^{2}=0.70\right)$, respectively] and (b) a per-unit dry weight basis [equations for fuchsia and chrysanthemum, where chlorophyll $\left(\mu \mathrm{g} \cdot \mathrm{g}^{-1} \mathrm{dry}\right.$ weight $)=17.50+0.14 \times \mathrm{DIF}\left(r^{2}=0.18\right)$ and $\left.24.45+0.45 \times \mathrm{DIF}\left(r^{2}=0.58\right)\right]$ (Erwin et al., 1991a). to $\mathrm{GA}_{3}$ associated with temperature was related to changes in receptor site number or phospholipid synthesis.

Recent research demonstrated the Lycopersicon esculentum mutant gib-1, which has a reduced ability to synthesize GA, responded more on an absolute and relative basis to $\mathrm{GA}_{3}$ application when plants were grown in a-DIF than a +DIF environment (unpublished data). Apparently, the DT/NT environment predisposed the tissue to respond to a given GA dose.

Supportive evidence for GA involvement in DIF effects on GA synthesis or tissue sensitivity to GA is seen in the effects of DIF on dioecious plants. GA (Jones and Zeevaart, 1980; Pharis and King, 1985) and DIF (Erwin, 1991; Erwin et al., 1992b, 1994a) affect flower sex expression. Applying GA to Agrostemma L. induced maleness (Jones and Zeevaart, 1980). In contrast, applying B995 (daminozide), a nonspecific GA biosynthesis inhibitor, induced femaleness in muskmelon (Cucumis melo L.) (Halevy and Rudich, 1967; Pharis and King, 1985). Cucurbita grown in a +DIF environment have significantly more male than female flowers (Fig. 12) (Erwin, 1991; Erwin et al., 1992b, 1994a). Conversely, Cucurbita plants grown in a 0 or -DIF environment have significantly more female than male flowers compared to plants grown in a + DIF environment. Although other factors, such as ethylene, can influence flower sex expression in Cucurbitacea, these results, combined with previous data on exogenous application of GA or GA biosynthesis inhibitors, provide additional evidence for GA involvement in plant stem elongation responses to DIF. In addition, applying the ethylene action inhibitor silver thiosulfate did not interact to affect stem elongation responses to DIF (unpublished data).

However, the effects of DIF on GA synthesis or tissue sensitivity to GA interact with irradiance, light quality, and photoperiod. We hypothesize that the block in GA synthesis occurs at the conversion step from $\mathrm{GA}_{19}$ to $\mathrm{GA}_{20}$, controlled via $\mathrm{GA}_{19}$-oxidase. This conversion via $\mathrm{GA}_{19}$-oxidase is light dependent and is believed to be associated with the basis for long-day stimulation of stem elongation (Zeevaart et al., 1991). Cool conditions in conjunction with a short day would, therefore, limit this conversion step and decrease elongation resulting from less conversion to bioactive GA. However, if DIF were elicited entirely via this conversion step, then increased irradiance would result in greater conversion and a decreased response to DIF; this is not the case.

\section{EFFECT OF DIF ON POSTHARVEST LIFE}

Reports on the effects of DIF on postharvest life of flowering plants have been inconclusive. Logic suggests that cool days and warm nights would reduce total endogenous carbohydrate levels over time. A manifestation of reduced carbohydrate status would be differences in plant dry weight between +DIFgrown and -DIF-grown plants. However, re- 
sults on the effects of DIF on plant dry weight have been conflicting (see previous section on DIF effects on carbon partitioning).

Miller et al. (1993) showed that Lilium carbohydrate content decreased as DIF decreased. Lilium postharvest life was significantly reduced only when plants were grown in an environment with a DT considerably below the NT (P.A. Hammer, personal communication). In contrast to these results, J.E. Erwin and R.D. Heins (personal observation) did not observe reduced postharvest life of DIF-grown vs. +DIF-grown Lilium, even when plants were grown with a -20C DIF. In contrast to Euphorbia and Lilium, Campanula postharvest life was longer for-DIF-grown

a
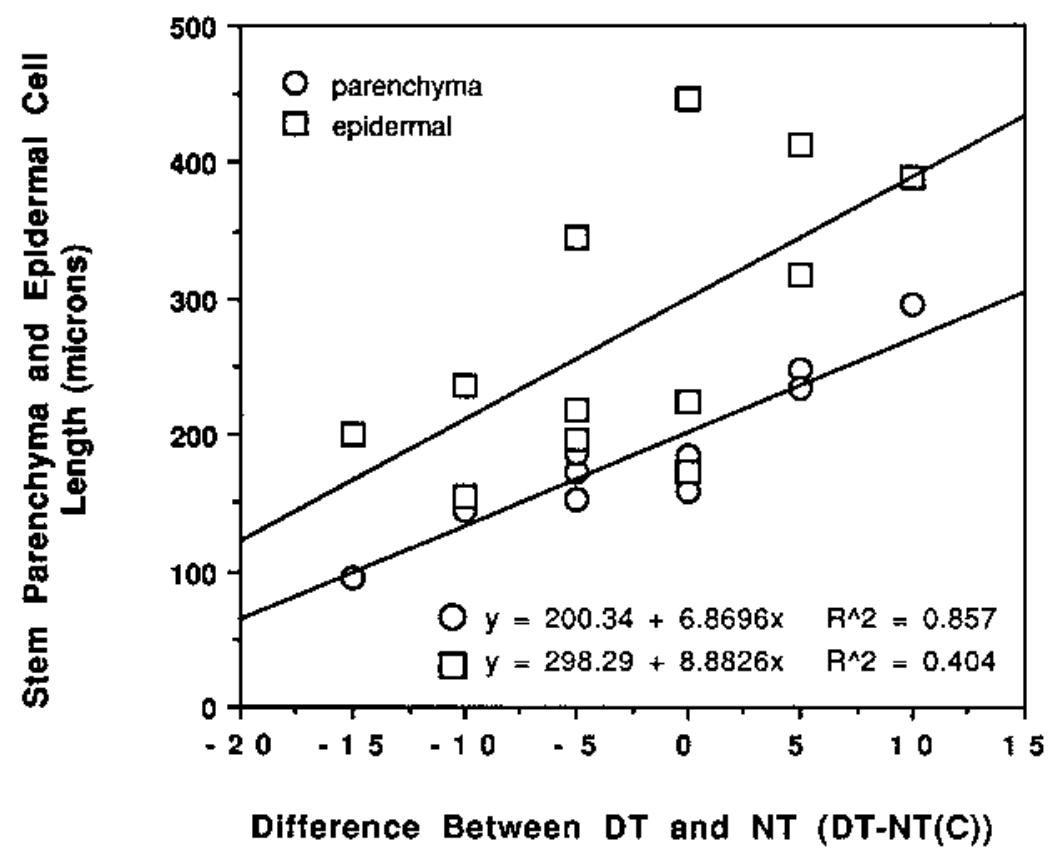

b

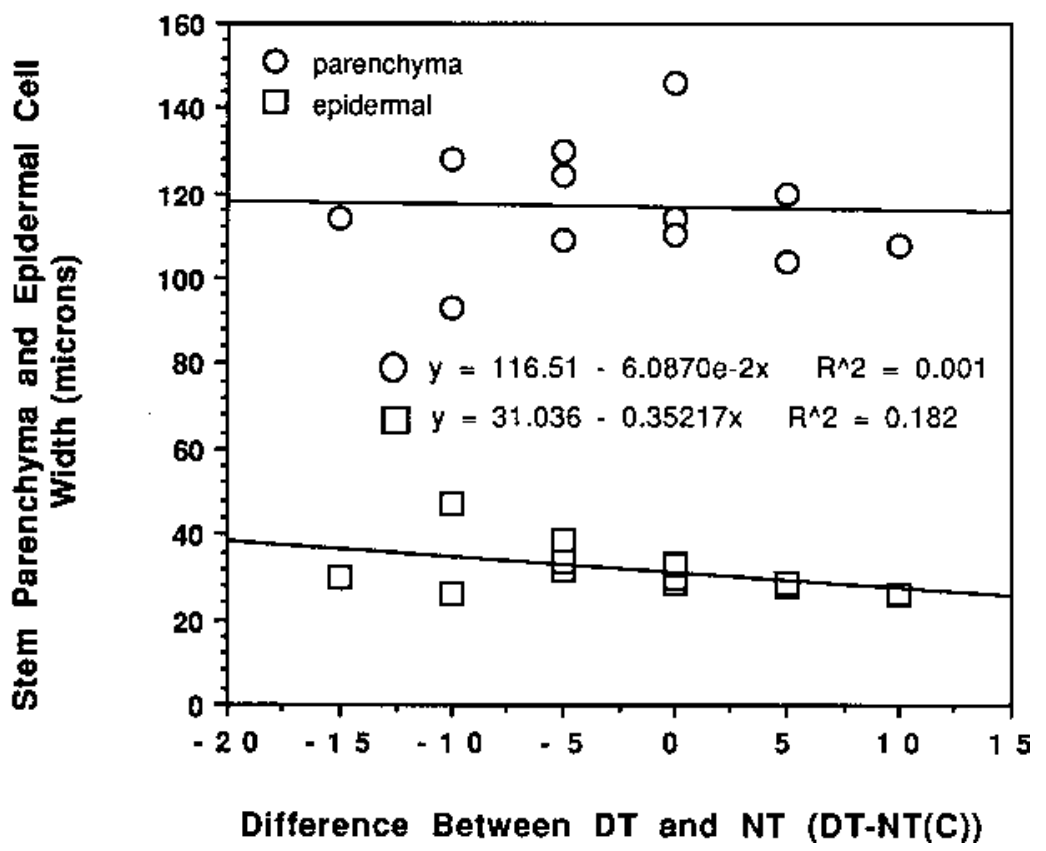

Fig. 10. The effect of day and night temperature (DT/NT) difference (DIF) on Lilium longiflorum 'Nellie White' central parenchyma and stem epidermal cell length (a) and width (b) (Erwin et al., 1991c, 1994b). Equations are as follows: stem parenchyma cell length $=200+6.87 \times \mathrm{DIF}\left(r^{2}=0.86\right)$, stem epidermal cell length $=298+8.88 \times \mathrm{DIF}\left(r^{2}=0.40\right)$, stem parenchyma cell width $=116-0.06 \times \mathrm{DIF}\left(r^{2}=0.00\right)$, and stem epidermal cell width $=31.04-0.35 \times \operatorname{DIF}\left(r^{2}=0.18\right)$.

plants than +DIF-grown plants (Serek, 1991).

Euphorbia cyathia abscission occurred more quickly on-DIF-grown vs. +DIF-grown plants after 2 weeks in a postharvest environment (Moe et al., 1992a). However, there was no significant difference between + DIF-grown vs. -DIF-grown plants after 3 or 4 weeks. More bract edge necrosis was observed on -DIFgrown Euphorbia 'Lilo' plants vs. 0 or +DIFgrown plants (Moe et al., 1992a). In contrast, Euphorbia 'Starlight' bract edge necrosis was not affected by DIF. Additional reports have suggested that -DIF-grown Euphorbia plants are at greater risk to develop bract edge necrosis than +DIF-grown plants (T.A. Nell and J.E. Barret, personal communication).

DIF probably interacts with other climatic factors to affect plant postharvest life. Specifically, irradiance and photoperiod before harvest probably influence the effect of DIF on any of the mentioned postharvest factors.

\section{MODELLING DIF EFFECTS}

Recent experimentation has successfully modeled DIF responses by showing two separate responses to DT and NT (S. Pearson, personal communication). However, dropping temperatures during the beginning of the photoperiod resulted in a greater reduction in stem elongation than could be modeled by a DT effect only (Ueber and Hendricks, 1992). A rapid drop in temperature at the beginning of the photoperiod appears to result in an aftereffect that suppresses elongation for an extended period.

\section{ECOLOGICAL SIGNIFICANCE}

The response of stem or cell elongation to DIF is an observation that leads to questions concerning the ecological or evolutionary significance of DIF responses. The dependence of stem elongation on DIF has been demonstrated across many plant species (Erwin, 1991; Heins and Erwin, 1990; Moe and Heins, 1990). The degree of response, however, varies (Erwin et al., 1994a; Heins and Erwin, 1990). The nature of the variation in species response to DIF suggests that species indigenous to tropical or woodland environments are less sensitive to DIF than species from temperate or prairie environments (J.E. Erwin, personal observation).

We hypothesize, stem elongation responses to DIF are a mechanism by which plant growth during various periods of a year maximizes stem elongation at critical times to permit effective competition in a plant community (Erwin et al., 1989a). The dependence of stem elongation on DIF is probably based on the indigenous environment of a plant and the degree of competition among plants in that community. Experiments are under way to determine the potential ecological significance of stem elongation responses to DIF.

\section{Literature Cited}

Berghage, R.D. 1989. Modeling stem elongation in Euphorbia pulcherrima. PhD diss. Michigan State Univ., East Lansing. 
a

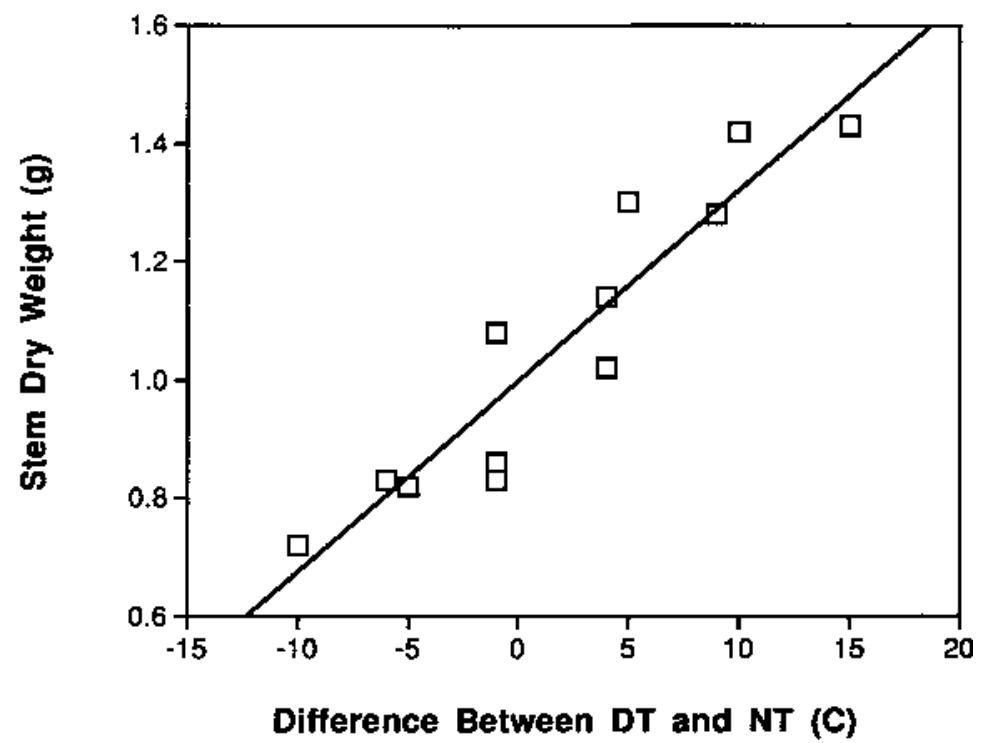

b

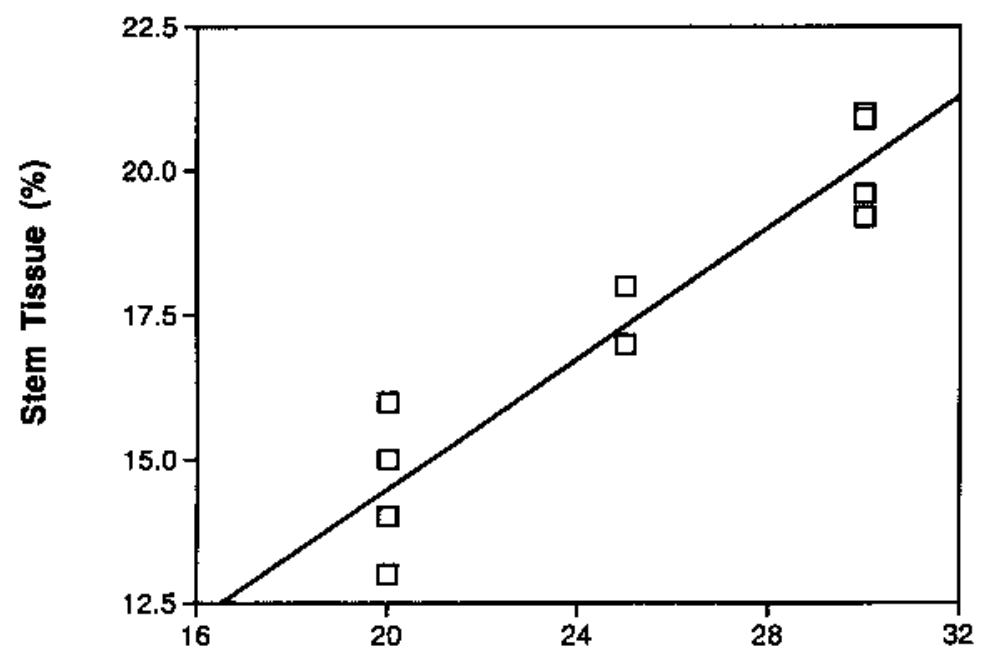

Day Temperature (C)

Fig. 11. The effect of day and night temperature (DT/NT) difference (DIF) on (a) stem dry weight of New Guinea impatiens (Erwin et al., 1992a) [stem dry weight $\left.=0.98+0.03 \times \mathrm{DIF}\left(r^{2}=0.85\right)\right]$. (b) The effect of DT on the percentage of a shoot dry weight that was partitioned to stem tissue [percent of total dry weight in stem tissue $\left.=3.76+0.55 \times \operatorname{DIF}\left(r^{2}=0.83\right)\right]$. Dry weights were collected on a representative branch from each of six plants grown under any of $16 \mathrm{DT} / \mathrm{NT}$ treatments.

Table 3. The effect of ancymidol (ANCY) and day/night temperature (DT/NT) difference (DIF) on Lilium longiflorum 'Nellie White' plant height at anthesis. Plant height was defined as the change in height from the start of the temperature treatments. Temperature treatments began 5 days after all plants had initiated flowers (Erwin et al., 1989b).

\begin{tabular}{|c|c|c|c|c|}
\hline \multirow{2}{*}{$\begin{array}{l}\mathrm{DT} / \mathrm{NT} \\
\left({ }^{\circ} \mathrm{C}\right)\end{array}$} & \multirow[b]{2}{*}{ DIF } & \multicolumn{2}{|c|}{ Plant ht (cm) } & \multirow{2}{*}{$\begin{array}{c}\text { Reduction } \\
(\%)\end{array}$} \\
\hline & & No ANCY & $0.50 \mathrm{mg} \mathrm{ANCY}$ & \\
\hline $25 / 15$ & +10 & $48.2^{\mathrm{z}}$ & $39.1^{\mathrm{y}}$ & $19^{*}$ \\
\hline $20 / 15$ & +5 & 46.5 & 36.5 & $22^{* *}$ \\
\hline $15 / 15$ & 0 & 36.0 & 30.4 & $16^{* *}$ \\
\hline $20 / 20$ & 0 & 35.8 & 31.2 & $13^{*}$ \\
\hline $15 / 20$ & -5 & 29.3 & 29.7 & $0^{\mathrm{NS}}$ \\
\hline $15 / 25$ & -10 & 29.1 & 30.1 & $-3^{\mathrm{Ns}}$ \\
\hline
\end{tabular}

${ }^{2}$ Numerals represent treatment means.

${ }^{y}$ Ancymidol was applied as two spray applications of $0.25 \mathrm{mg}$ each. Applications were made 7 and 14 days after flower initiation.

ss,*,**Nonsignificant or significant at $P \leq 0.05$ or 0.01 , respectively.

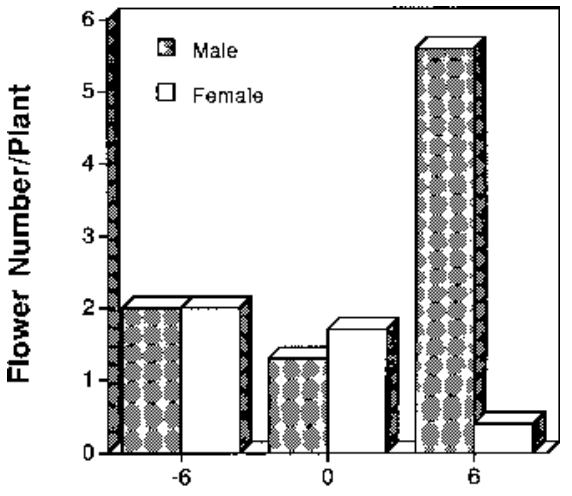

Difference Between DT and NT $\left({ }^{\circ} \mathrm{C}\right)$

Fig. 12. The effect of day and night temperature (DT/NT) difference (DIF) on Cucurbita 'TayBelle' flower sex expression. Data were collected 60 days after germination. Thermoperiod and photoperiod length were $12 \mathrm{~h}$. Temperature treatments were $17 \mathrm{DT} / 23 \mathrm{C}$ NT (-6C DIF), 20 DT/20C NT (0C DIF), or 23 DT/17C NT (+6C DIF) (Erwin, 1991; Erwin et al., 1994a).

Berghage, R.D., J.E. Erwin, and R.D. Heins. 1991a. Photoperiod influences leaf chlorophyll content in chrysanthemum grown with a negative DIF temperature regime. HortScience 26:92.

Berghage, R.D. and R.D. Heins. 1990. Modelling poinsettia stem elongation. J. Amer. Soc. Hort. Sci. 116:14-18.

Berghage, R.D., N. Lownds, J.E. Erwin, and R.D. Heins. 1991b. Circadian temperature effects on nutrient content of poinsettia leaves. HortScience 26:713.

Biddington, N.L. 1986. The effects of mechanically-induced stress in plants-A review. Plant Growth Regulat. 4:103-123.

Bidinotto, R.J. 1990. The great apple scare. Reader's Digest, October.

Blacquière, T. and J.A. Bakker. 1992. First European workshop in thermo- and photomorphogenesis on cultivation of ornamentals. Acta Hort. 305.

Dale, J.E. 1964. Some effects of alternating temperature on the growth of French bean plants. Ann. Bot. N.S. 28:127-135.

Dale, J.E. 1965. Leaf growth in Phaseolus vulgaris. II. Temperature effects and the light factor. Ann. Bot. 29:293-308.

Erwin, J.E., 1991. Thermomorphogenesis in plants. PhD diss. Michigan State Univ., East Lansing.

Erwin, J.E., M. Ascerno, F. Pfleger, and R.D. Heins. 1992a. New Guinea impatiens production. Minnesota Com. Flower Growers Bul. 41:1-15.

Erwin, J.E., R.D. Berghage, and R.D. Heins. 1991a. Circadian temperature effects on plant chlorophyll content. HortScience 26:105.

Erwin, J.E. and R.D. Heins. 1988. Effect of diurnal temperature fluctuations on stem elongation circadian rhythms. HortScience 23:820.

Erwin, J.E. and R.D. Heins. 1990. Temperature effects on lily development rate and morphology from the visible bud stage until anthesis. J. Amer. Soc. Hort. Sci. 115:644-646.

Erwin, J.E. and R.D. Heins. 1991. Diurnal variations in temperature affect carbon partitioning in New Guinea impatiens and fuchsia shoots. HortScience 26:117.

Erwin, J.E., R.D. Heins, R.D. Berghage, B.J. Kovanda, W.H. Carlson, and J.A. Biernbaum. 1989a. Cool mornings can control plant height. GrowerTalks 52:73-74.

Erwin, J.E., R.D. Heins, W. Carlson, and S. New-

HortScience, Vol. 30(5), August 1995 
port. 1992b. Environmental and mechanical manipulation of stem elongation. PGRSA Quarterly $20: 1-17$

Erwin, J.E., R.D. Heins, and M.G. Karlsson. 1989b. Thermomorphogenesis in Lilium longiflorum Thunb. Amer. J. Bot. 76:47-52.

Erwin, J.E., R.D. Heins, and R. Moe. 1991b. Temperature and photoperiod effects on Fuchsia $\times$ hybrida morphology. J. Amer. Soc. Hort. Sci. 116:955-960.

Erwin, J.E and G Pierson. 1992. Interaction between diurnal temperature fluctuations and gibberellins on Lycopersicon stem elongation and chlorophyll content. HortScience 27:657.

Erwin, J.E., M. Strefeler, and R.D. Heins. 1994a. Diurnal temperature fluctuations affect vegetable development. Minnesota Com. Flower Growers Bul. 42:6-10.

Erwin, J.E., P. Velguth, and R.D. Heins. 1991c. Diurnal variations in temperature affect cellular elongation but not division. HortScience 26:105.

Erwin, J.E., P. Velguth, and R.D. Heins. 1994b Diurnal temperature fluctuations affect Lilium cell elongation but not division. J. Expt. Bot. 45:1019-1025

Grindal, G. and R. Moe. 1994. Effects of temperature-drop and a short dark interruption on stem elongation and flowering in Begonia $\times$ hiemalis Fotsch. Scientia Hort. 57:123-132.

Halevy, A.H. and J. Rudich. 1967. Modification of sex expression in muskmelon by treatment with the growth retardant B-995. Physiol. Plant 20:1052-1058.

Heins, R.D. and J.E. Erwin. 1990. Understanding and applying DIF. Greenhouse Grower 8:7378.

Heins, R.D. and J.E. Erwin. 1991. The history of DIF and the use of a morning temperature dip to control plant height. Minnesota Com. Flower Growers Bul. 40:1-4

Hendricks, L. 1991. Diff bei Beet- und Balkonpflanzen. Gb+Gw 39:1883-1889.

Jacobsen, L.H., M.G. Amsen, and O.F. Nielsen. 1991. Negative DIF: Mean room temperature control and its effect on short-day plants. Tidsskr. Planteavl 95:441-447.

Jaffe, M.J. 1973. Thigmomorphogenesis: The response of plant growth and development to mechanical stimulation. Planta 114:143-157.

Jensen, H.E.K. 1993. Influence of duration and placement of a high night temperature on morphogenesis of Dendranthema grandiflora Tzvelev. Scientia Hort. 54:327-335.

Jones, M.G. and J.A.D. Zeevaart. 1980. The effect of photoperiod on the levels of seven endogenous gibberellins in the long-day plant Agrostemma githago L. Planta 149:274-279.

Karlsson, M.G. 1986. Temperature and irradiance effects on Dendranthema grandiflorum cv 'Bright Golden Anne' growth and development. PhD diss. Michigan State Univ., East Lansing.

Karlsson, M.G. and R.D. Heins. 1992. Chrysanthemum dry matter partitioning patterns along irradiance and temperature gradients. Can. J. Plant Sci. 72:307-316

Karlsson, M.G., R.D. Heins, J.E. Erwin, R.D Berghage, W.H. Carlson, and J.A. Biernbaum. 1989. Temperature and photosynthetic photon flux influence chrysanthemum shoot development and flower initiation under short-day conditions. J. Amer. Soc. Hort. Sci. 114:158-163.

Kaczperski, M.P. 1989. Influence of temperature and irradiance on growth and development of Petunia Xhybrida 'Snow Cloud'. MS thesis. Michigan State Univ., East Lansing.

Kozai, T., S. Kushihashi, C. Kubota, and K. Fujiwara. 1992. Effect of difference between photoperiod and dark period temperatures, and photosynthetic photon flux density on the shoot length and growth of potato plantlets in vitro. J. Jpn. Soc. Sci. 61:93-98.

Langton, F.A., K.E. Cockshull, C.R.J. Cave, and E.J. Hemming. 1992. Temperature regimes to control plant structure: Current UK R\&D. Acta Hort. 327:49-59.

Latimer, J.G. 1991. Mechanical conditioning for control of growth and quality of vegetable transplants. HortScience 26:1456-1461.

Latimer, J.G. 1993. Mechanical conditioning of greenhouse-grown transplants. HortTechnology 3:412-414.

Latimer, J.G. and P.A. Thomas. 1991. Application of brushing for growth control of tomato transplants in a commercial setting. HortTechnology 1:109-110.

Lecharny, A., H. Scwall, and E. Wagner. 1985. Stem extension rate in light-grown plants. Plant Physiol. 79:625-629.

Lockhart, J.A. 1958. The response of various species of higher plants to light and gibberellic acid. Physiol. Plant. 11:478-486.

Ludolph, D. 1992. Height control of ornamental plants without chemical growth retardants. Ohio Florist's Bul. 748:1-4.

Miller, W. 1991. Try mechanical stress as a "natural" growth regulator. GrowerTalks 55:81-85.

Miller, W.B., P.A. Hammer, and T.I. Kirk. 1993 Reversed greenhouse temperature after carbohydrate status in Lilium longiflorum Thunb. 'Nellie White'. J. Amer. Soc. Hort. Sci. 118:736740 .

Milthorpe, F.L. 1959. Studies on the expansion of the leaf surface. I. The influence of temperature. J. Expt. Bot. 10:233-249.

Mitchell, C.A., C.J. Severson, J.A. Wott, and P.A. Hammer. 1975. Seismomorphogenic regulation of plant growth. J. Amer. Soc. Hort. Sci. 100:161165

Moe, R., T. Fjeld, and L.M. Mortensen. 1992a. Stem elongation and keeping quality in poinsettia (Euphorbia pulcherrima Willd.) as affected by temperature and supplementary lighting. Scientia Hort. 50:127-136.

Moe, R., N. Glomsrud, I. Bratberg, and S. Valso. 1992b. Control of height in poinsettia by temperature drop and graphical tracking. Acta Hort. 327:41-48.

Moe, R. and R.D. Heins. 1990. Control of plant morphogenesis and flowering by light quality and temperature. Acta Hort. 272:81-89.

Moe, R., R.D. Heins, and J.E. Erwin. 1991. Effect of day and night temperature alterations, and plant growth regulators on stem elongation and flowering of the long-day plant Campanula isophylla Morettii. Scientia Hort. 48:141-151.

Moe, R. and L.M. Mortensen. 1992. Second European Symp. on thermo- and photomorphogenesis in plants. Acta Hort. 327

Mortensen, L.M. and R. Moe. 1992. Effects of various day and night temperature treatments on the morphogenesis and growth of some greenhouse and bedding plant species. Acta Hort. 327:77-86.

Pharis, R.P. and R.W. King. 1985. Gibberellins and reproductive development in seed plants. Annu. Rev. Plant Physiol. 36:517-568.

Pinthus, M. and J. Meiri. 1979. Effects of the reversal of day and night temperatures on tillering and on the elongation of stem and leaf blades of wheat. J. Expt. Bot. 30:319-326.

Roberts, D.R. 1991. DIF. Greenhouse Manager April:52-55.

Serek, M. 1991. Post-harvest characteristics of Campanula carpatica: Influence of temperature programming. Gartenbauwissenschaft 56:71-74.

Singh, S.P. and L.G. Paleg. 1984. Low temperatureinduced $\mathrm{GA}_{3}$ sensitivity of wheat. I. Characterization of the low temperature effect on isolated aleurone of kite. Plant Physiol. 76:139-142.

Singh, S.P. and L.G. Paleg. 1985a. Low temperature-induced $\mathrm{GA}_{3}$ sensitivity of wheat. III. Comparison of low temperature effects on alphaamylase induction by aleurone tissue of dwarf, and tall wheat. Austral. J. Plant Physiol. 12:269275 .

Singh, S.P. and L.G. Paleg. 1985b. Low temperature-induced $\mathrm{GA}_{3}$ sensitivity of wheat. IV. Comparison of low temperature effects on the phospholipids of aleurone tissue of dwarf, and tall wheat. Austral. J. Plant Physiol. 12:277-289.

Smith, D.R. and R.W. Langhans. 1961. The influence of day and night temperatures on the growth and flowering of the Easter lily (Lilium longiflorum Thunb. var. Croft). J. Amer. Soc. Hort. Sci. 80:593-598.

Tageras, H. 1979. Modifying effects of ancymidol and gibberellins on temperature induced elongation in Fuchsia $\times$ hybrida. Acta Hort. 91:411417.

Tutty, J.R., P.R. Hicklenton, and D.N. Kristie. 1992 The dynamics of chrysanthemum stem elongation in relation to day and night temperatures. Acta Hort. 305:61.

Tutty, J.R., P.R. Hicklenton, D.N. Kristie, K.B McRae. 1994. The influence of photoperiod and temperature on the kinetics of stem elongation in Dendranthema grandiflorum. J. Amer. Soc. Hort. Sci. 119:138-143.

Ueber, E. and L. Hendricks. 1992. Effects of intensity, duration and the time of a temperature drop on growth and flowering of Euphorbia pulcherrima Willd. ex Klotzsch. Acta Hort. 327:33-37.

Vogelezang, J., L. Cuijpers, and M. de Graaf- v.d. Zande. 1992a. Growth regulation of bedding plants by reversed day/night temperature only? Acta Hort. 305:37-43.

Vogelezang, J., R. Moe, H. Schussler, L. Hendricks, L. Cuijpers, and E. Ueber. 1992b. Cooperative European research on temperature strategies for bedding plants. Acta Hort. 327:11-16.

Went, F. 1944. Plant growth under controlled conditions. II. Thermoperiodicity in growth and fruiting of the tomato. Amer. J. Bot. 31:135150 .

Went, F.W. 1952. The effect of temperature on plant growth. Annu. Rev. Plant Physiol. 4:347-362.

Went, F.W. 1957. The experimental control of plant growth. Chron. Bot. 17:1-126.

Zeevaart, J.A.D., M. Talon, and T.M. Wilson, 1991. Stem growth and gibberellin metabolism in spinach in relation to photoperiod, p. 273-279. In: N Takahashi, B.O. Phinney, and J. MacMillan (eds.). Gibberellins. Springer-Verlag, New York.

Zieslin, N. and M.J. Tsujita. 1988. Regulation of stem elongation of lilies by temperature and the effect of gibberellin. Scientia Hort. 37:165-169. 